Marikina, M. (2018). The Impact of Ecological Regulations and Management on National Competitiveness in the Balkan States. Journal of Competitiveness, 10(4), 120-135. https://doi.org/10.7441/ joc. 2018.04 .08

\title{
THE IMPACT OF ECOLOGICAL REGULATIONS AND MANAGEMENT ON NATIONAL COMPETITIVENESS IN THE BALKAN STATES
}

\section{- Maria Marikina}

\begin{abstract}
The object of this research is to describe the impact that ecological regulations and management have on the national competitiveness in the Balkan states. The thesis of the present article is that increasing regulation along with the development of ecological sustainability will lead to higher competitiveness in the Balkan states of Albania, Bulgaria, Greece, Romania, Croatia and Serbia. The effect of basic ecological regulations and management will be shown and analysed both in the region as a whole as well as on a state-by-state basis in terms of national competitiveness, with the correlation between the ecological regulation and competitiveness measured. The time frame reflected is from 2013 to 2017, and a Pearson linear correlation will be applied. In a summary and conclusion, we shall show that regulation plays a prominent role both in reaching ecological sustainability, as well as in the positive development of the Balkan states' competitiveness.
\end{abstract}

Keywords: competitiveness, regional economic activity, sustainable development, economics of the environment JEL Classification: Q01, R11, R58

Received: April, 2018

1st Revision: October, 2018

Accepted: November, 2018

\section{INTRODUCTION}

Competitiveness is one of the main characteristics and driving forces of the world economy today, including the Balkan peninsula. Competitiveness enhances the economic freedom of the actors and at the same time creates conditions for self-realisation through the development and creation of new competitive goods and services. In the accelerated processes of globalisation, internationalisation, technological transformations and new types of regulation, issues related to national competitiveness have become evident.

Forming a clear and thorough definition of the modern view on competitiveness is not easy. This is mainly because one must take into account different levels of economy, forming factors, as well as conditions in which the actors are placed, measurement criteria, etc. In this respect, national competitiveness is related to the complex understanding that it represents an opportunity to maintain high levels of productivity of labour and capital, while using system innovations to 
reach sustainable economic growth, together with an increase in the real income of the public. However, competitiveness is more than that. It is also a development mechanism between two states or economic unions, and the essence lies in whether a state has given up on its positions or has won them over another state in the course of active competition.

\section{THEORETICAL BACKGROUND}

\subsection{National Competitiveness of the Balkan States}

In order to analyse and understand the above-mentioned complex category and its specific representations, the Balkan states, which are on equal terms in respect to their competitiveness, were chosen. Albania, Bulgaria, Greece, Romania, Croatia and Serbia are all economies of states at the second level of competitiveness development, i.e. a level driven by effectiveness according to the World Economic Forum's methodology for measuring national competitiveness (see Appendix 1). Attention shall be devoted to several foundational aspects of this definition.

Firstly, competitiveness is related to productivity - "the set of institutions, policies and factors that determine the level of productivity of a country" (Schwab, 2017), i.e. the amount of real product produced by a unit of an invested production factor. And since productivity may be viewed as a function of the intensity of factors used, managerial effectiveness, technologies, along with opportunities for the labour force affected by differential payment, this criterion manifests only one piece of evidence regarding labour stimuli for the place and share of each economy among other competing economies. In other words, higher growth in the accounted productivity is highly likely to bring about higher levels of competitiveness.

Next, we come to the inclusion of innovations as well as the application of inventions in the production process of new goods, without which competition between entrepreneurs, fields of economy and regions would not be possible: "competitiveness of companies and countries depend on their capabilities to make innovations and their orientation to technology and information" (Dogan, 2016). This has an especially powerful meaning in the 21st century as the speed of technological changes, including in the Balkans, is very high, and one of the priority goals in most of the economies is growth.

Thirdly, in understanding competitiveness, one should determine a clear definition - sustainable economic growth - related to increasing the real income of the public, a criteria which is "synonymous to national wellbeing and productivity" (Krugman, 1994), along with the "ability to reach high living standards and economic growth" (Delgado et al., 2012). Negatives such as the lack of priority regarding environmental protection, ecological incompliance, unfair income distribution, and the potential adverse effects of disturbing of the economic effectiveness of existing market models within the Balkan economies must be taken into consideration.

Finally, an understanding of competitiveness is related in general to active competition, as traditionally in economic theory and as well as in practice competition is connected to a certain amount of aggression and/or attraction. Competitiveness is simply the ability to compete. In the core of some of the Balkan economies which strive to increase active competition, there are certain incentives that should attract larger flows of direct foreign investment, create higher 
profits and increase export. In another perspective, the "economies of other countries reach high level of competitiveness because they are more attractive. They have qualities that signify and ease direct foreign investments, and the possibilities for making of profits and export." (sic) (Marikina, 2017).

In today's conditions of regionalization and globalization and considering the Balkan states at the national level, many new obstacles of different types have emerged which have an impact on the character of competitiveness in strongly expressed dynamics. This situation is influenced by development of world markets, changes in economic policies and priorities both led by and submitted to governments, technological changes, industrial development, as well as the specific national capabilities towards adapting the states to the new requirements, especially the new ecological regulations. In the course of today's economic development of the Balkan states, the organizational models of the economies are changing together with ongoing testing processes regarding the most important elements in compliance with ecological regulations and overall management. In phases when changes occur, new management and large scale organizational economic and social schemes are adopted. What is more, efforts are being made to advance competitiveness to business organisations and the strategic sectors of national economies. Thus, national models of market economy are being formed which possess relevant characteristics and competitive advantages towards other market economies. This means that in the organizational models new policies are being implemented, structural and technological changes instituted, concepts for market development re-framed, and management techniques for the further organizational development of business connections are being applied. The foundations for such claims are that the elements of private and state enterprises within existent economic models are being modified for the long-run; these enterprises are entering into harsh competition with respect to expenses, state environmental policies, etc.

Attention has to be turned to the fact that the states' abilities to maintain the positive aspects of their models depend on transformational changes in the world economy, the long-term prediction of developmental processes, the challenges posed by new regulations, including ecological ones such as technological standards, environmental taxes, guidelines on emissions trading, etc. The economies of the Balkan states are striving to reach cooperation and competence at the level of the most important actors, a situation which is creating technical-organizational and social conditions for dynamic changes, world market-facing development, and higher competitiveness. This also means accepting the economic challenges stemming from the new ecological regulations and management mechanisms attempting to reach a certain ecological sustainability and opportunity toward the realisation of national competitive advantages.

\subsection{Ecological Regulations - Principles, Instruments, and Possible Conflicts}

Ecological regulations in the Balkan states, like those of developed market economies, consists of collections of administrative-legal and economic principles as well as techniques to influence production in accordance with the requirements for environmental quality standards and sustainable development of the national economy, as "sustainability evokes positive associations" (Calliott \& Mumford, 1997) and, according to Allen \& Hoekstra (1993), "everyone agrees that sustainability is a good thing". Based on individual instruments and the means used in the man- 
agement of economic and social systems, ecological regulation influences the structural reformation of the economy and politics in the field of protection and recreation of environment; this influences the production conjuncture and the market, technical progress as well as ecological sustainability. In the end, all of these factors affects national competitiveness.

Ecological regulation and management starts with various administrative and legal measures, i.e. norms and rules for the limitation of impact on the environment by means of granting licenses and controlling documents, prescriptions and bans, most of which interfere with production conditions and bring additional expenses to businesses. In practice, one observes adherence to the principles of ecological regulation in the necessary direction for ecological sustainability of the economy. In the Balkan states, ecologisation is found in the activities carried out by each separate state; the conspicuous use of limited natural resources is being avoided, and the principle of "use while you still can" is slowly being replaced by "use the resources effectively, as they are available to everyone". It is known that limiting environmental damage is consequential regarding the function of the economy, and loss limitation is related to additional expenses or "external expenses" and many conflicts stem from solving them.

In the first place, acts have been passed regarding production plants, which must be regulated in line with the "polluter-must-pay-principle" (Rennings et al., 1999), i.e. whoever damages the environment is obliged to reimburse the state in full for the additional costs to compensate for the damage caused as well as for future protection measures. All additional ecological expenses, the law states, will have a negative impact on the economic results of the actors involved (increase prices; reduce income and competitiveness).

Secondly, additional expenses for the environment should be spread across all manufacturers and the public as a whole. The burden should be distributed in a way that will not create a negative influence on the economic state of individual manufacturers.

In practice, it is difficult to determine which part of the chain of manufacturers this in fact harming the environment, thus ecological regulations should be applied in order to reach environmental quality at minimal costs relative to the scale of the whole economy. The final goal of management is reaching sustainable development, i.e. economically effective, ecologically compliant and socially acceptable growth, which is the main purpose of ecological regulation.

In the Balkan states, one leading idea is that the instruments for application of regulations in the field of environment and ecology (respectively, planning) must be related for the most part by the application of the right form of management.

Management in respect to the environment has developed and is applied mainly as a reaction to the fast growth and expansion of ecological activities, for which at the governmental level separate branches have been formed to act as regulators of activities related to the environmental issues. At the beginning, the policies were limited mainly to measures within national economies and powers of the state organs; later, with the inclusion of more institutions (especially the EU members) that have interests and influence in the field, positions were taken along with responsibilities for ecological issues. This regulation in the Balkan states is both direct and indirect in respect to the instruments used, and the responsibility of the creators of (potential) ecological issues becomes heavier and heavier. 
Direct measures that are being used for regulating behaviour towards the environment include legal directives which lead to imminent change with respect to the environment. Traditional instruments of this kind consists of legislation "developed as a direct consequence from the policies and regulatory frameworks and usually incompliance with of these is punished by issuance of sanctions" (Knopp, 2008). This is how the actions with negative impact on the ecology have become subject to administrative control characterised by legal requirements for information, registration, licensing, permission, approval and other procedures for authorizing participation in such activities. Direct regulation is also exercised by restrictive legal ordinances or such that require certain action in compliance with a specific act such as the following:

- Absolute legal restrictions, which directly forbid certain behaviours which negatively impact the environment;

- Authorisation procedures, which form a significant instrument in the regulatory framework in the field of ecology. It is strictly forbidden without due authorisation to carry out projects which require such express authorisation. "Activities for the building or exploitation of facilities that influence the environment, using components of the environment or manufacturing and dealing of certain products may be subject to authorisation proceedings" (Knopp, 2008).

- Legislation in the sphere of the environment, which includes ecological obligations that are imposed on all members of society or on a certain group. Usually the basic obligations include preventive measures, mostly for the preservation of natural resources such as water and soil. Together with these basics, numerous "additional obligations that may benefit environmental protection, such as obligations for popularisation and presentation, monitoring and protection, obligations for cooperation and obligatory accounting of certain information, organizational obligations and such for tolerance to certain actions" are also envisaged. (Knopp, 2008).

Indirect measures for regulating the behaviour towards environment in the Balkan states as a whole do not rely on ordinances, but rather seek to influence motivation. Thus certain stimuli are envisaged towards following eco-friendly behaviour while still providing freedom to act. To the set of instruments for indirect measures for the regulation of behaviour, the following have been added: awareness, economic measures, such as taxes, fees, ecological certificates, etc.

- Awareness in the Balkan states is still not a very powerful instrument, thus what is sought is an increase in sensitivity and ecological consciousness via political and moral appeals, warnings, recommendations and other forms of information provided (e.g. product labels, product information and possible means of use);

- Among the economic measures, the most important means of indirect regulation are the taxes and fees related to behaviours which influence the environment. Of course, the issues that arise must be documented; they stem from the inability to directly influence the behaviour towards environment through taxes and fees, which, if they are too low, the polluters will choose to pay instead of changing their harmful behaviour. If they are too high, on the other hand, they can distort the conditions for economic competitiveness. 
- Other instruments consist of stimuli for consumers of eco-products, which are defined by ordinances that limit the use of products harmful for the environment in comparison with products compliant with ecological standards. As these standards are not imposed by law, these stimuli are considered more as a soft-law, and hence a product that has attained those standards is considered cleaner than another product of the same type which has not.

- In recent years, an especially effective form has proven to be ecological certificates, which have turned out to be very effective for the Balkan states. The logic behind introducing certificates for environmentally friendly behaviour is based on the market-compliant form of quantitative control exercised by the state. It is known that these schemes, which are based on certificates, do not put price definition as their starting point, but, rather, define the quantitative frame for acceptable levels of future use of natural resources or elements of the environment while leaving the market to form the sector for trading within this acceptable quantity. This is the scheme agreed upon in global politics for environmental protection within the Kyoto Protocol. It provides for emission quotes which give to their owner the right to pollute the environment within the limit set out by the respective quote. Following this, if the owner pollutes less than what is provided for, it can then sell its unused quotas to another polluter. Thus, companies are able to make a choice as to whether to adopt measures for emissions reduction or to buy additional quotas from other companies which have managed to reduce their emissions with lower expenses.

\section{RESEARCH OBJECTIVE, METHODOLOGY AND DATA}

The question posed here is how the ecological regulation and management affect the national competitiveness and what proof can one find for that? The effect of basic ecological regulations and management will be shown and analysed within the region or on a state-by-state basis, taking into account their correlation with national competitiveness. The fact is that in the last years, in the Balkan states, the role of economic instruments is growing as they become the mandatory addition to legal acts, norms and rules, regulating the behaviour towards environment. At the same time, it is clear that a single "correct" norm does not exist, neither does a pack of instruments. They all have to be chosen and applied in such a way, so to reach the best balance between differing interests of the consumers of environment or natural resources, the interests of those affected by the actions of the actors, the interests of the public and the environmental protection purposes. The legislators and the administrations in the end are forced to use their experience mostly in production systems. All regulations for environmental protection, and more specifically, the ecological ones, have a role in encouraging companies to reduce pollution, make it expensive for producers and increase their production costs. There are two contradictory views on the impact of environmental regulations on the production costs. "The conventional perspective suggests that environmental regulations damage the economic performance of regulated (usually pollution intensive) industries because they increase production costs leading to lower productivity or profitability. Moreover, where there are differences in environmental regulations applied to firms competing for the same market, higher costs and lower productivity can influence market share. Proponents of this view suggest that polluting industries in open economies will tend to gravitate towards regions with lenient environmental policy." (Dechezleprêtre \& Sato, 
2014). Those two views, however, may be considered old-fashioned and insufficient in respect to the final result - national competitiveness of the Balkan states, to date only a few significant studies explore and test the effect of environmental regulations on competitiveness in Europe. For example, De Vries \& Withagen (2005) focus on SO2 reduction-related innovation and test the "weak" Porter Hipothesis at the country-level on a sample of 12 European countries plus US and Canada. Johnstone et al. (2017) also focused on the Porter Hipothesis in the renewable energy sector in 25 OECD countries and research the relation between environmental regulations and patents using various environmental policy tools. Carrión-Flores and Innes (2010) examine the connection between environmental patents and emissions, which proxies for environmental policy stringency, using statistical data for 127 manufacturing industries for a long period: 1989-2004. Mulatu et al. (2001) present a statistically supported evaluation in order to assess what the main conclusions regarding the relationship between the environmental regulation and competitiveness are when it comes to studies on international trade flows. Albrizio \& Zipperer (2014) make a very important contribution with study of seventeen OECD countries and they find a significant and positive effect of a Pollution Intensity Index on total factor productivity at both sector and firm level. Kneller \& Manderson (2012) investigate on manufacturing industries in UK and relate innovation, proxied by either research and development or capital investment, to expenditures on end-of-pipe pollution control and the operation of pollution control equipment. One may rather seek grounds that support the thesis for direction in which ecological regulations influence national competitiveness in the hypothesis expressed by Michael Porter in 1991. According to it, regulation of environment may lead to private companies and economies as a whole to become more competitive in international perspective, while providing stimuli for ecological compliance, which would not have occurred had the politics not been there (Porter, 1991).

Grounds for such statement may be found in the following:

- First, regulations in ecological aspect tell producers which resources are possibly ineffective, how they should be used, as well as the potential for technological improvement.

- Second, regulations unify producers in collecting and distributing data, such as, for example, the best practices in technology, which leads to making considerable benefits for increasing the informational supply of companies and overcoming the organizational inertia.

- Third, regulations in the environment reduce insecurity, which leads investment to more precious objects.

- Four, ecological regulations create force that may motivate innovation and research activities. The idea is that innovation among producers often compensates all additional regulationstemming expenses (Jaffe \& Palmer, 1997).

- Five, ecological regulations are, after all, transitional and are instrument of the government to measure the "pulse" of national economy. Being flexible, regulations give opportunity predict the impact certain policies may have, and so to choose regulatory mechanisms and instruments that will encourage innovation and competitiveness. Thus ecological regulations play a role of normative receipt for positive acclaim of the current policy of each government. 
To move on to empirical evidence for the fact that introduction of ecological regulations and management brings about higher competitiveness of the Balkan states, a calculation of Pearson's correlation coefficient will be applied. For this purpose, we shall use appropriate indicators that show the ecological regulation and management. They contain synthesized information and data about activities that are related to environmental regulation and management. They also broadly summarize the already mentioned direct and indirect measures for the environmental regulation. The first such indicator is the GDP per unit of energy use, which means "Purchasing power parity gross domestic product (PPP\$ GDP) per kilogram of oil equivalent of energy use". The second is environmental performance, as this index ranks countries on 20 performance indicators tracked across policy categories that cover both environmental public health and ecosystem vitality. These indicators gauge how close countries are to established environmental policy goals. The third one is ISO 14001 environmental certificates as ISO 14001:2015 sets out the criteria for an environmental management system and can be certified to. These three indicators serve for the formation and evaluation of a certain ecological sustainability of the economies. Data used are representative and are part of the analyses and interactive database for the Global Innovation Index (GII) - result of a collaboration between Cornell University, INSEAD, and the World Intellectual Property Organization (WIPO) as co-publishers, and their Knowledge Partners.

The first indicator - GDP per unit of energy use provides information for energy intensity and thus defines how much energy is necessary to reach economic value in an economy. High energy intensities show the price for turning energy into GDP, while high energy intensity means high industrial production as an element of GDP. Requirements and regulations for general living standards and climate conditions of the economy have a direct impact on the overall energy intensity of the economies of the Balkans. Here we include a wide array of regulations that influence energy efficiency of appliances and buildings (by using building materials and methods, such as insulation), fuel economy of transport vehicles, distances driven by vehicles, better methods and types of transport, capacity and usefulness of mass transit, energy-used or conservational efforts, energy sources outside the grid and stochastic economic shocks such as energy disruptions caused by natural disasters, mass electricity supply outings, unexpected new sources, energy efficiency or energy subsidies for the common energy intensity of the nation.

For the second indicator, the foundational evaluation of the overall system of programs for reduction of environmental pollution and limitation of negative consequences on the public health and related to this wide array of regulations. These regulations stem from the constant modernisation and improvement of the process of management of the environment and health in providing timely and trustworthy information for the state of the environment and public health and to establish the connection between polluting the environment and the overall state of public health (Council of Ministers, Bulgaria, 2008). Efficiency within the overall system depends on an ever-increasing number of regulations in the form of laws, rules and ordinances as well as their implementation in each state, i.e. on the information instruments for the management of environment and health, control measures, economic and administrative regulators and institutional structures by states towards research activities and technological development related to the relevant issues. Public health regulations and those affecting the environmental 
quality by components and harmful factors consist of the following: water, air, soils, waste, hazardous chemical compounds and chemicals, ionizing and non-ionizing radiation, noise, cataclysms, industrial and nuclear accidents, living and business environment, etc. Special attention is devoted to the systems of activities related to the overall regulation of economic sectors: energy, industrial, transport, agriculture, tourism and the management carried out in respect to emission reduction and transporter transfer of polluters, by improvement of the structure of used fuels, increasing their usage efficiency and energy economy, stimulating the development of economically efficient renewable energy sources, creating conditions for the limitation of the energy losses as well as promotion of energy economy measures, etc. (Council of Ministers, Bulgaria, 2008).

The third indicator "ISO 14001 defines requirements for the environment management system, which may be integrated with other requirements for management, so as to help the organizations to reach their economic goals as well as the goals related to the environment" (GDPR, ISO 14001:2015). The main purpose of this indicator is the identification and evaluation of the aspects related to environment, and thus organizations strive to reduce the negative impact of their activities. The newest version is from 15.09.2015, with one important certificate now ISO $14001-2015$.

The specifics of the introduction to this certificate include:

- Determination of the context of the organization and related thereto risks which could influence the accomplishment of goals and increase the achievement of results with respect to the environment;

- Evaluation and management of risks related to threats and opportunities;

- Voluntary tasks related to the environment and active information exchange with stakeholders;

- Pointing out the responsibility of executive management to take a leading position in improving results respective to the environment;

- Concepts for the life-cycle of the product, including actions after delivery, use, and postuse;

- Increased control over exported processes;

- Understanding of the needs and expectations of stakeholders.

By introducing this certificate, organizations increase their capacity to manage their ecological issues, which leads to better ecological markers, the risk of ecological disasters as well as reducing their impact, increasing the environmental consciousness of personnel, control of resources usage leading also to expenses reduction. Applying the organization requirements, obtaining permissions and compliance with their conditions, etc. has begun in earnest.

In order to present the impact of ecological regulations and management in terms of competitiveness, data from the World Economic Forum (WEF) will be used here from its annual reports. In their preparation, different approaches were taken in order to enable the presentation of the Global Competitiveness Index (GCI) consisting of data from more than 140 states which reflect 
the macroeconomic aspects of competitiveness. For the calculation of this index 12 factors were taken into account with a different weight for each of the components. The GCI aggregates the latest economic ideas for competitiveness and, at the same time, takes into account considerations regarding the complexity of the process of reaching economic growth, including calculating the average value of a vast amount of different components, each of which is reflected into one or more particular aspect of competitiveness (see Appendix 2).

\section{RESULTS AND DISCUSSION}

Thanks to the data from the GCI, the present researchers were given an opportunity to examine the competitiveness of each state, including those in the Balkans, based on certain factors. At the same time, the index provides overall information about business activities, and the policy-makers thus have an instrument that allows them to evaluate objectively the strengths and weaknesses of national economies along with their place among other participants in active competition. The Research result in the index also provides an opportunity to change the policies of governments in order to achieve higher competitiveness. This possibility has been acknowledged unequivocally by the national economies that we tag as having formed the factors for competitiveness indicated in the present research. This data is especially valuable, as it encompasses the full spectrum of possible factors for competitiveness which are the focus of the actions carried out by the states included in the end of the competitiveness evaluation set by the Index of Global Competitiveness. What correlations do we find in the Balkan states?

In order to research the correlation between the factors GDP per unit of energy use, environmental performance and ISO 14001 environmental certificates respectively X1, X2, X3 and the indication competitiveness - $\mathrm{Y}$ for the relevant years, a correlation analysis must be carried out which will determine the degree that impact factors X1, X2, X3 have over the indication $\mathrm{Y}$ or the presented functional dependence of the type: $\mathrm{Y}=\mathrm{f}(\mathrm{x})$. The correlation method of analysis provides an opportunity to express the unknown relations between the factors with the greatest influence on the changes of the values of the indication. As a result of the correlation analysis, the type of dependence between the factor and the indication, found to be linear, was determined.

In the case concerned, there are two values, where $\mathrm{X}$ are regulations, and $\mathrm{Y}$ is competitiveness. The sample includes simultaneous observations $(x 1, y 1), \ldots,(x 3, y 5)$ which are presented in the tables for the states in the research for the respective years from 2013 to 2017, where the joint distribution of $\mathrm{X}$ and $\mathrm{Y}$ is evident (see Tables 1-6).

Tab. 1 - Albanian competitiveness and ecological regulations; correlation. Source: Data extracted from Global Innovation Index and Global Competitiveness Index online database

\begin{tabular}{|l|l|l|l|l|l|l|}
\hline Albania & 2013 & 2014 & 2015 & 2016 & 2017 & Correl - r \\
\hline Competitiveness - Y & 3.85 & 3.84 & 3.93 & 4.06 & 4.18 & \\
\hline Ecological sustainability & 41.2 & 44.5 & 46 & 48.2 & 52.5 & 0.946166715 \\
\hline $\begin{array}{l}\text { GDP per unit of energy } \\
\text { use }-\mathrm{X}_{1}\end{array}$ & 54.6 & 54 & 56 & 41.9 & 46 & -0.79854631 \\
\hline
\end{tabular}




\begin{tabular}{|l|l|l|l|l|l|l|}
\hline $\begin{array}{l}\text { Environmental perform- } \\
\text { ance }-\mathrm{X}_{2}\end{array}$ & 65.9 & 54.7 & 54.7 & 74.4 & 74.4 & 0.775546388 \\
\hline $\begin{array}{l}\text { ISO 14001 environmental } \\
\text { certificates }-\mathrm{X}_{3}\end{array}$ & 3.2 & 4.9 & 8.7 & 8.5 & 21.9 & 0.909405744 \\
\hline
\end{tabular}

Tab. 2 - Bulgarian competitiveness and ecological regulations; correlation. Source: Data extracted from Global Innovation Index and Global Competitiveness Index online database

\begin{tabular}{|c|c|c|c|c|c|c|}
\hline Bulgaria & 2013 & 2014 & 2015 & 2016 & 2017 & Correl - r \\
\hline Competitiveness - Y & 4.31 & 4.37 & 4.32 & 4.44 & 4.46 & \\
\hline Ecological sustainability & 49.2 & 51.9 & 51.2 & 59.4 & 57.1 & 0.936492658 \\
\hline $\begin{array}{l}\text { GDP per unit of energy } \\
\text { use- } \mathrm{X}_{1}\end{array}$ & 21.4 & 20.1 & 20.8 & 15.1 & 22.7 & -0.28331852 \\
\hline $\begin{array}{l}\text { Environmental perform- } \\
\text { ance- } \mathrm{X}_{2}\end{array}$ & 56.3 & 64 & 64 & 83.4 & 83.4 & 0.959623326 \\
\hline $\begin{array}{l}\text { ISO } 14001 \text { environmental } \\
\text { certificates- } \mathrm{X}_{3}\end{array}$ & 70 & 91.4 & 86.1 & 100 & 73.3 & 0.259161824 \\
\hline
\end{tabular}

Tab. 3 - Greek competitiveness and ecological regulations; correlation. Source: Data extracted from Global Innovation Index and Global Competitiveness Index online database

\begin{tabular}{|l|l|l|l|l|l|l|}
\hline Greece & 2013 & 2014 & 2015 & 2016 & 2017 & Correl - r \\
\hline Competitiveness - Y & 3.93 & 4.04 & 4.02 & 4 & 4.02 & \\
\hline Ecological sustainability & 39.4 & 49.2 & 52 & 53.7 & 56 & 0.789264597 \\
\hline $\begin{array}{l}\text { GDP per unit of energy } \\
\text { use - X }\end{array}$ & 44 & 41.8 & 42.3 & 36.7 & 41.1 & -0.32663442 \\
\hline $\begin{array}{l}\text { Environmental perform- } \\
\text { ance - } \mathrm{X}_{2}\end{array}$ & 60 & 73.3 & 73.3 & 85.8 & 85.8 & 0.631198852 \\
\hline $\begin{array}{l}\text { ISO 14001 environmental } \\
\text { certificates- } \mathrm{X}_{3}\end{array}$ & 14 & 16.1 & 28.8 & 23.3 & 26.3 & 0.501250023 \\
\hline
\end{tabular}

Tab. 4 - Romanian competitiveness and ecological regulations; correlation. Source: Data extracted from Global Innovation Index and Global Competitiveness Index online database

\begin{tabular}{|l|l|l|l|l|l|l|}
\hline Romania & 2013 & 2014 & 2015 & 2016 & 2017 & Correl - r \\
\hline Competitiveness - Y & 4.13 & 4.3 & 4.32 & 4.32 & 4.28 & \\
\hline Ecological sustainability & 41.2 & 44.5 & 46 & 48.2 & 52.5 & 0.59392 \\
\hline $\begin{array}{l}\text { GDP per unit of energy } \\
\text { use- } \mathrm{X}_{1}\end{array}$ & 54.6 & 54 & 56 & 41.9 & 46 & -0.3375 \\
\hline $\begin{array}{l}\text { Environmental perform- } \\
\text { ance- } \mathrm{X}_{2}\end{array}$ & 65.9 & 54.7 & 54.7 & 74.4 & 74.4 & -0.1222 \\
\hline
\end{tabular}




\begin{tabular}{|l|l|l|l|l|l|l|}
\hline $\begin{array}{l}\text { ISO } 14001 \text { environmental } \\
\text { certificates- } \mathrm{X}_{3}\end{array}$ & 3.2 & 4.9 & 8.7 & 8.5 & 21.9 & 0.33067 \\
\hline
\end{tabular}

Tab. 5 - Croatian competitiveness and ecological regulations; correlation. Source: Data extracted from Global Innovation Index and Global Competitiveness Index online database

\begin{tabular}{|l|l|l|l|l|l|l|}
\hline Croatia & 2013 & 2014 & 2015 & 2016 & 2017 & Correl - r \\
\hline Competitiveness - Y & 4.13 & 4.13 & 4.07 & 4.15 & 4.19 & 0.450152427 \\
\hline Ecological sustainability & 49.7 & 53.3 & 55.1 & 62.9 & 62.4 & 0.56015 \\
\hline $\begin{array}{l}\text { GDP per unit of energy } \\
\text { use- X }\end{array}$ & 38.1 & 38.1 & 38.5 & 30.9 & 36.3 & -0.43806594 \\
\hline $\begin{array}{l}\text { Environmental perform- } \\
\text { ance- X }\end{array}$ & 64.2 & 62.2 & 62.2 & 87 & 87 & 0.773909603 \\
\hline $\begin{array}{l}\text { ISO 14001 environmental } \\
\text { certificates- X }\end{array}$ & 46.9 & 65.9 & 73.9 & 78.6 & 65.6 & -0.11890259 \\
\hline
\end{tabular}

Tab. 6 - Serbian competitiveness and ecological regulations; correlation. Source: Data extracted from the Global Innovation Index and Global Competitiveness Index online

\begin{tabular}{|l|l|l|l|l|l|l|}
\hline Serbia & 2013 & 2014 & 2015 & 2016 & 2017 & Correl - r \\
\hline Competitiveness - Y & 3.77 & 3.9 & 3.89 & 3.97 & 4.14 & \\
\hline Ecological sustainability & 35.7 & 49.5 & 48.4 & 50 & 47 & 0.562776002 \\
\hline $\begin{array}{l}\text { GDP per unit of energy } \\
\text { use- } \mathrm{X}_{1}\end{array}$ & 19.7 & 19.3 & 20.7 & 12.1 & -0.67647745 \\
\hline $\begin{array}{l}\text { Environmental perform- } \\
\text { ance- } \mathrm{X}_{2}\end{array}$ & 46.1 & 69.1 & 69.1 & 78.7 & 78.7 & 0.842236464 \\
\hline $\begin{array}{l}\text { ISO 14001 environmental } \\
\text { certificates- }\end{array}$ & 50.3 & 70.6 & 62.1 & 68.9 & 77.7 & 0.908619885 \\
\hline
\end{tabular}

The joint distribution of metric values $\mathrm{X}$ and $\mathrm{Y}$ is normal. The statistical dependence between these, included in the data from the sample, is expressed in the sample coefficient of linear correlation - Pearson coefficient $(r)$.

The linear coefficient of correlation as an indicator of statistical dependence between regulations and competitiveness is here characterised by direction and force, respectively. Thus the correlation coefficient $\mathrm{r}$ is interpreted as a sign and absolute value. For the states indicated in the research with respect to environmental performance and ISO 14001 environmental certificates (excluding the environmental performance in Romania and ISO 14001 environmental certificates in Croatia), the sign is "+", which means that there is a directly proportional correlation - the rise in ecological regulations is related to the growth of competitiveness. As for GDP per unit of energy use, the sign is "-" for all Balkan states, which means the presence of inversely proportional correlation, i.e. the growth of one variable is related to reduction of the other. Taking into account the GDP per unit of energy and energy intensity as shown above, this means that the growth of GDP per unit of energy use shall be related to an ever-growing spectre of regulations which affect energy efficiency. 
In respect to the absolute values of the coefficients for correlation between GDP per unit of energy use and competitiveness, they are largest in Albania and Serbia and lowest in Bulgaria and Greece (maximum absolute value of $\mathrm{r}$ is 1 ), and respectively in these states, the stronger it is, the weaker the relation mentioned is. For competitiveness, the second group of coefficients from the correlation of environmental performance, it is largest in Bulgaria, followed by almost identical values for Albania and Croatia, and the lowest for Greece. As the absolute values of coefficients of correlation in ISO 14001 environmental certificates and competitiveness, the highest values are for Albania and Serbia, and lowest for Croatia and Romania.

For the period 2013 to 2017, it can be stated that for all of the Balkan states shown, there is improvement in the competitiveness index as well as in the ranking among all 140 states in the world that were included in the General Research for Global Competitiveness (see Table 7).

Tab. 7 - Global Competitiveness Index (2013-2017). Source: World Economic Forum. 20122018. The Global Competitiveness Index 2012-2018 rankings

\begin{tabular}{|c|c|c|c|c|c|c|c|c|c|c|}
\hline year & 2013 & & 2014 & & 2015 & & 2016 & & 2017 & \\
\hline country & score & rank & score & rank & score & rank & score & rank & score & rank \\
\hline Albania & 3.85 & 95 & 3.84 & 97 & 3.93 & 93 & 4.06 & 80 & 4.18 & 75 \\
\hline Bulgaria & 4.31 & 57 & 4.37 & 54 & 4.32 & 54 & 4.44 & 50 & 4.46 & 49 \\
\hline Greece & 3.93 & 91 & 4.04 & 81 & 4.02 & 81 & 4.00 & 86 & 4.02 & 87 \\
\hline Romania & 4.13 & 76 & 4.30 & 59 & 4.32 & 53 & 4.30 & 62 & 4.28 & 68 \\
\hline Croatia & 4.13 & 75 & 4.13 & 77 & 4.07 & 77 & 4.15 & 74 & 4.19 & 74 \\
\hline Serbia & 3.77 & 101 & 3.90 & 94 & 3.89 & 94 & 3.97 & 90 & 4.14 & 78 \\
\hline
\end{tabular}

Bulgaria was shown to be most competitive state of the shown in this research, followed by Romania and Croatia. In the fourth and fifth position respectively are Albania and Serbia, with Greece in sixth place. Taking into account the complex character of national competitiveness and the data shown here, it is clear that in the Balkan states we may identify a large degree economic prosperity. Development is occurring such as growing production-, innovation-, knowledge-, competitiveness- and efficiency-based levels in every ecological aspect of economies, factors that provide growing standards of living and high levels of employment. These economic effects are also influenced by growing ecological sustainability (see Tables 1-6), i.e. supporting activities which have a positive impact on the protection and improvement of environment, such as the reduction and recycling of waste, energy efficiency, increasing awareness in respect to sustainable development, and, where suitable, special seminars supporting environment-related projects, and courses on environmental management.

\section{CONCLUSION}

National economies differ in the way they manage challenges and connections in the active competition in the world economy and achieve their competitiveness. Many challenges and correlations, including those related to environment and having impact on national competitiveness, bring about strongly expressed dynamics in the economies' behaviour. They are oriented more 
and more towards behaviours that lead to a higher productivity, higher profit and greater sustainability. The respective regulations also have an impact on changes in economic policies led by governments in terms of technological changes, industrial development and specific national abilities for tuning and transforming the states in regards to the new requirements and new market development along with meeting criteria for ecological sustainability. In the respective phases of such changes, new management schemes are being implemented which are valid for the larger part of the economy and the general public.

The analysis in this work concerns the dynamic presentation of competitiveness of the Balkan states with the purpose of determining whether economic results in terms of competitiveness and ecological implementations in terms of regulations and management are correlated. The complexity of competitiveness is evaluated, with regulations and environmental management synthesised in terms of the possible effects they may have on the environment. Specifically, this is expressed by GDP per unit of energy use, which provides information regarding energy intensity and thus defines how much energy is necessary to reach the economic value in an economy by the evaluation of the overall system of programs for reduction of environmental pollution along with the limitation of negative consequences on the public health. A wide array of regulations and requirements for the environment management system has been instituted which may be integrated into other requirements for management so as to help the organizations to reach their economic and environmental goals. The concept was to evaluate how these ecological regulations influence competitiveness.

Based on the research, it is evident that ecological effects and economic results are correlated. What is more, we have proven the statement that in the Balkan states, increasing regulatory capacity and management in the environmental field and ecology is related to growing competitiveness.

\section{References}

1. Albrizio. S., \& Zipperer V. (2014). Empirical Evidence on the Effects of Environmental Policy Stringency on Productivity Growth. Economics department Working papers. № 1179. OECD. Paris. http://dx.doi.org/10.1787/5jxrjnb36b40-en

2. Allen. T. F. H., \& Hoekstra T. W. (1993). Toward a definition of sustainability. Available at: https://www.fs.fed.us/rm/pubs_rm/rm_gtr247/rm_gtr247_098_107.pdf

3. Callicott J. B., \& Mumford K. (1997). Ecological Sustainability as a Conservation Concept. Conservation Biology, 11 (1), 32-40. http://dx.doi.org/10.1007/978-94-017-1337-5_3

4. Carrion-Flores. C. E., \& Innes R. (2010). Environmental Innovation and Environmental Performance. Journal of Environmental Economics and Management, 59 (1), 27-42. https://dx.doi. org /10.1016/j.jeem.2009.05.003

5. Council of Ministers. Bulgaria. (2008). National Environmental and Health Action Plan, 15-18. Available at: http://ncphp.government.bg/files/NatProgrEnvHealth_approved\%2018_12_ 2008.pdf 
6. Dechezleprêtre A., \& Sato M. (2014). The impacts of environmental regulations on competitiveness. Review of Environmental Economics and Policy, 11 (2), 183-206. https://dx.doi. org $/ 10.1093 /$ reep/rex013

7. Delgado. M., Ketels. C., Porter. M. E., \& Stern. S. (2012). The determinants of national competitiveness. Nber Working Paper Series. Working Paper. https://dx.doi.org/10.3386/ w18249

8. Dogan E. (2016). The Effect of Innovation on Competitiveness. Ekonometri ve Istatistik Sayl. $24,60-81$.

9. GDPR. ISO 14001:2015 in https://www.consejo.bg/iso-14001_11_16

10. The Global Innovation Index Reports. (2017). Cornell Insead Wipo. 2012-2017. Available at: https://www.globalinnovationindex.org/gii-2017-report

11. Guidelines for Environmental Sustainability - Operational Program. Available at http:// ophrd.government.bg/view_file.php/7845

12. Garelli. S. (2006). Competitiveness of nations: The fundamentals. IMD World Competitiveness Yearbook. Available at: http://www.imd.org/uupload/www01/ documents/ wcc/content/fundamentals.pdf

13. ISO 14001. (2015). Environmental Management Systems ISO 14001. Available at: https://www. consejo.bg/iso-14001_11_16

14. Jaffe. A. B., \& Palmer, K. (1997). Environmental Regulation and Innovation: A Panel Data Study. Review of Economics and Statistics, 79 (4), 610-619.

15. Johnstone, N., Hascic I., \& Popp D. (2017). Renewable Energy Policies and Technological Innovation: Evidence Based on Patent Counts. Environmental and Resource Economics, 68 (2), 441-444. http://dx.doi.org/10.1007/s10640-017-0176-x

16. Kneller. R., \& Manderson E. (2012). Environmental Regulations and Innovation Activity in UK Manufacturing Industries. Resource and Energy Economics, 34 (2), 211-235.

17. Knopp, L. (2008). International and European Environmental Law with Reference to German Environmental Law. Berlin: Lexicon Verlagsgesellschaft.

18. Krugman, P. (1994). Competitiveness: A dangerous obsession. Foreign Affairs, 73 (2), 28-44. http://dx.doi.org/10.2307/20045917

19. Marikina, M. (2017). National Competitiveness - attractiveness or/and aggressiveness. Eurasian Journal of Economics and Finance, 5 (2), 66-72. http://dx.doi.org/10.15604/ ejef.2017.05.02.005

20. Mulatu A., Florax R. J. G. M., \& Withagen C. A. A. M. (2001). Environmental Regulation and Competitiveness. Amsterdam: Tinbergen Institute Discussion paper.

21. Porter, M. (1991). Towards a Dynamic Theory of Strategy. Strategic Management Journal, 12 , 95-117.

22. Rennings K., Koschel H., Brockmann K. L., \& Kühn, I. (1999). A Regulatory Framework for a Policy of Sustainability: Lessons from the Neo-Liberal School. Ecological Economics, 28 (2), 197-212. http://dx.doi.org/10.1016/S0921-8009(98)00038-X 
23. Schwab, K. (2017). The Global Competitiveness Report 2017/2018. Available at: http://www3. weforum.org/docs/GCR2017-2018/05FullReport/TheGlobal CompetitivenessReport2017 $\% \mathrm{E} 2 \% 80 \% 932018$.pdf

24. De Vries, F. P. \& Withagen C. (2005). Innovation and Environmental Stringency: The Case of Sulfur Dioxide Abatement. CentER Discussion Paper N. 2005-18. Tilburg University. Available at: https://pure.uvt.nl/ws/portalfiles/portal/773169/18.pdf

25. World Economic Forum. (2018). The Global Competitiveness Index 2012-2018 rankings. Available at: http://reports.weforum.org/global-competitiveness-report-2012-2018/ rankings/

26. World Economic Forum. (2014). Global competitiveness report 2014-2015. Available at: http://www3.weforum.org/docs/WEF_GlobalCompetitivenessReport_2014-15.pdf

27. World Economic Forum. (2016). Global competitiveness report 2016-2017. Available at: http://www3.weforum.org/docs/GCR2016-2017/05FullReport/TheGlobalCompetitivenes sReport2016-2017_FINAL.pdf

\section{Contact information}

assoc. prof. Maria Marikina. Ph.D.

Department of Economics

Faculty: General Economics

University of National and World Economy, Sofia, Bulgaria

E-mail:mmarikina@unwe.eu

\section{Appendix 1: Classification by each stage of development}

World Economic Forum. 2018. "Global competitiveness report 2017-2018”. Methodology and Computation of the Global Competitiveness Index 2017-2018. Classification by each stage of development. p.320 Available at: http://www3.weforum.org/docs/GCR2017- 2018/05FullReport/TheGlobalCompetitivenessReport2017\%E2\%80\%932018.pdf

\section{Appendix 2:}

12 pillars according to WEF: Institutions. Infrastructure. Macroeconomic environment. Health and primary education. Higher education and training. Goods market efficiency. Labour market efficiency. Financial market development. Technological readiness. Market size. Business sophistication. Innovation 